\title{
Separation of the genera in the subtribe Cassiinae (Leguminosae: Caesalpinioidae) using molecular markers
}

Laxmikanta Acharya ${ }^{1,4}$, Arup Kumar Mukherjee ${ }^{2}$ and Pratap Chandra Panda ${ }^{3}$

Recebido em 8/07/2009. Aceito em 1/03/2011

\begin{abstract}
RESUMO
(Separação dos gêneros na subtribo Cassiinae (Leguminosae: Caesalpinioidae) utilizando marcadores moleculares). Técnicas de Random amplified polymorphic DNA (RAPD), Inter simple sequence repeat (ISSR) e Amplified Fragment Length Polymorphism markers (AFLP) foram utilizadas para verificar a segregação do gênero Cassia L. senso lato em três diferentes gêneros, Chamaecrista Moench., Senna P. Mill. e Cassia L. senso stricto Dezoito representantes dos três táxons foram caracterizados com o uso de marcadores moleculares: 25 RAPD, seis iniciadores ("primers") ISSR e seis AFLP combinações de iniciadores, resultando na amplificação de 612, 115 e 622 bandas (loci), respectivamente. A maioria dos loci apresentou-se como polimórfico, mostrando um alto grau de diversidade genética entre os táxons estudados. O dendrograma construído com base nos dados de RAPD, ISSR e AFLP e agrupamento com procedimentos SHAN dividiu Cassia L. senso lato em três diferentes agrupamentos, chamados de Chamaecrista Moench., Senna P. Mill. e Cassia L. senso stricto Valores altos de bootstrap revelaram que todos os agrupamentos foram estáveis e robustos. Foi observado pela presente investigação que estes gêneros possuem identidade ao nível molecular, o que sustenta a elevação do genero Cassia L. senso lato para o nível de subtribo e a segregação dos três gêneros ao invés de formarem categorias infra-genéricas.
\end{abstract}

Palavras-chave: AFLP, Cassia, filogenia molecular, ISSR, RAPD

\begin{abstract}
(Separation of the genera in the subtribe Cassiinae (Leguminosae: Caesalpinioidae) using molecular markers). Random amplified polymorphic DNA (RAPD), Inter simple sequence repeat (ISSR) and Amplified fragment length polymorphism (AFLP) markers were used to verify the segregation of the genus Cassia L. senso lato into three distinct genera namely Chamaecrista Moench., Senna P. Mill. and Cassia L. sensostricto Eighteen representatives of the three taxa were characterized using the molecular markers. 25 RAPD, six ISSR primers and six AFLP primer combinations resulted in the amplification of 612, 115 and 622 bands (loci) respectively. Most of the loci are found to be polymorphic, showing high degrees of genetic diversity among the different taxa studied. The dendrogram constructed on the basis of the RAPD, ISSR and AFLP data using SHAN clustering, divided Cassia L. senso lato. into three different clusters as Chamaecrista Moench. Senna P. Mill. and Cassia L. senso stricto High bootstrap value revealed that all the clusters were stable and robust. It was observed from the present investigation that these genera have their identity at molecular level, which supports the elevation of the genus Cassia L. senso lato to the level of subtribe Cassiinae and segregation into three distinct genera instead of intrageneric categories.
\end{abstract}

Key words: AFLP, Cassia, ISSR, Molecular phylogeny, RAPD

\section{Introduction}

Cassia L. senso lato (Leguminosae: Caesalpinioideae) is one of the twenty-five largest genera of dicotyledonous plants in the world. The genus extends in all terrestrial habitats from the equator to the edges of dry and cold deserts, but much of its diversity is centred in areas of varied topography with seasonal climates. There has been considerable divergence of opinion concerning the delimitation and taxonomic status of its three constituent subgenera. Irwin \& Barneby $(1981,1982)$ proposed an improved classification and raised the genus Cassia L. to the level of subtribe Cassiinae; the latter comprised of three genera, viz Cassia L. senso stricto,

\footnotetext{
Siksha 'O’ Anusandhan University, Centre of Biotechnology, Jagamara, Khandagiri, Bhubaneswar, Orissa, India

2 Regional Plant Resource Centre, Division of Plant Biotechnology, DNA Finger Printing Laboratory, Nayapalli, Bhubaneswar, Orissa, India

3 Regional Plant Resource Centre, Taxonomy and Conservation Division, Bhubaneswar, Orissa, India

4 Author for correspondence: laxmikanta.acharya@gmail.com
} 
Senna P. Mill. and Chamaecrista Moench. This concept had found wide recognition in recent years (Randel 1988, 1989,1990; Lock 1988, 89; Larsen \& Hou 1996). Despite several studies by taxonomists, either on the whole subfamily Caesalpinioideae in restricted areas or of certain genera throughout the world, there is still a great deal of taxonomic work to be done at the level of genus and tribe. The taxonomic treatment of the genus Cassia L. senso lat. has been done in some countries in Asia, namely Malaysia (De Wit 1955) and Pakistan (Ali \& Quraishi 1967). But nowadays taxonomy is not simply based on floral and vegetative characters but many other types of data, like anatomical, cytological, serological and molecular. These are regarded as very important in determining relationships and affinities of the plants. New trends and new information on various aspects had prompted modern taxonomists to propose a new system of classification. These have also led to some changes in the criteria for determining the evolutionary status of the various taxa in the subtribe Cassinae.

Irwin and Barneby $(1981,1982)$ raised the genus Cassia L. sensu lato to the level of subtribe and elevated previous subgenera to generic rank viz. Senna Mill and Chamaecrista Moench under the tribe Cassieae Bronn ex Irwin and Barneby of Caesalpiniaceae (today LeguminosaeCaesapinioideae). However there is little work done on the molecular phylogeny of this genus and conformation of the trifurcation of this group. There are very few reports on other aspects like biochemical and cytological on this taxa. The reports that are present contradict each other in the cytological data (Singh 2001).

Keeping all these facts the present investigation was carried out with the objectives to derive an authentic relationship among the studied genera of the subtribe Cassiinae. Justification of trifurcation of the subtribe into three distinct categories like Cassia, Senna and Chamaecrista as suggested by Irwin and Barneby (1982), taking the molecular data obtained from RAPD, ISSR and AFLP analyses.

\section{Material and methods}

\section{Plant material}

All plants were raised from seed. Eighteen species of the genus Cassia were taken for the present study. Their taxonomic rank and changed names are given in Tab.1. They were grown in the nursery of Regional Plant Resource Centre, Bhubaneswar, Orissa, India. Very young and tender leaves were taken for genomic DNA isolation. Vouchers were deposited at Herbarium of Regional Plant Resource Centre.

\section{Molecular Analysis}

DNA was isolated from young, fresh leaves using the CTAB method as described by Saghai-Maroof et al.
(1984). For RAPD analysis, PCR amplification of 25ng of genomic DNA was carried out using standard 30 decamer oligonucleotide primers, out of which in 25 primers reproducible amplification was found. So they are taken for the present RAPD analysis and those are OPA02, OPA03, OPA04, OPA10, OPA16, OPA18, AF14, OPC02, OPC05, OPD02, OPD03, OPD07, OPD08, OPD18, OPD20, OPN02, OPN04, OPN05, OPN06, OPN08, OPN10, OPN11, OPN12, OPN16 and OPN18 (Operon Tech. Alameda, CA. USA). The RAPD analysis was performed as per the standard methods of Williams et al. (1990). PCR products were separated on a $1.5 \%$ agarose gel containing ethidium bromide solution (@0.5 $\mathrm{\mu g} / \mathrm{ml}$ of gel solution). The size of the amplicons was determined using size standards (100bp ladder plus or DNA ladder mix, MBI Fermentas, Lithuania). DNA fragments were visualized under UV light, documented in Gel Doc (Bio-Rad, USA) and photographed. Inter-simple sequence repeats have recently been developed which access the variation in the numerous microsatellite regions distributed throughout different genomes (basically the nuclear genome) and bypass the challenges of characterizing individual loci that other molecular techniques require. The PCR products were separated in polyacrylamide gel. Amplified fragment length polymorphism analysis was done as per the standard protocol of Vos et al. (1995) and the protocol supplied by the manufacturer (Invitrogen, USA). All the reagents and chemicals were procured from Invitrogen (Invitrogen life technology, CA, USA). After the completion of the gel run it was stained with $0.0002 \%$ of ethidium bromide and destained in distilled water. Gel was documented in a gel doc (Gel Doc 2000, Bio Rad, USA).

\section{Data analysis}

The bands amplified from RAPD, ISSR and AFLP were scored as ' 1 ' and ' 0 ' for presence and absence of band respectively. All the bands whether monomorphic or polymorphic were used for similarity calculation in order to avoid over estimation of distance (Gherardi et al. 1998). Jaccard's coefficient of similarity (Jaccard 1908) was calculated and a dendrogram based on similarity coefficient was obtained through unweighted pair group method using arithmetic averages (UPGMA) (Sneath \& Sokal 1973) and SHAN clustering. All the analysis was done using the computer package NTSYS-PC-2.02e (Rohlf 1997). Resolving power (Rp) of the RAPD, ISSR and AFLP was calculated as per Prevost \& Wilkinson (1999). Resolving power is: $\mathrm{Rp}=\Sigma \mathrm{IB}$ (IB (Band informative ness) $=1-[2 \times(0.5-\mathrm{P})], \mathrm{P}$ is the proportion of the 18 species containing the band. Primer Index (PI) was calculated from the polymorphic index. A polymorphic index (PIC) was calculated as PIC $=1-\times P_{i}^{2}, P_{i}$ is the band frequency of the $i$ th allele (Smith et al. 1997). In the case of RAPDs, ISSRs and AFLP the PIC was considered to be $1-p^{2}-q^{2}$, where $p$ is band frequency and $q$ is no band frequency (Ghislain et al. 1999). PIC value was then used to 
Table 1. Details of species with locality of collection, field number, habit and chromosome number in Cassinae*.

\begin{tabular}{|c|c|c|c|}
\hline Name of the species & $\begin{array}{l}\text { Chromosome } \\
\text { number }\end{array}$ & Habit & $\begin{array}{l}\text { Locality with field } \\
\text { collection number }\end{array}$ \\
\hline $\begin{array}{l}\text { Senna tora (Linn.) Roxb. } \\
\text { (Cassia tora Linn.) }\end{array}$ & $2 \mathrm{n}=24,26,28,52$ & Herb or under shrub & $\begin{array}{l}\text { R.P.R.C., BBSR. } \\
\text { LKA } 7643\end{array}$ \\
\hline $\begin{array}{l}\text { Senna occidentalis (Linn.) Link } \\
\text { \{Cassia occidentalis Linn. } \\
\text { Senna occidentalis (Linn.) Roxb.\} }\end{array}$ & $\begin{array}{c}2 \mathrm{n}=28 \\
\mathrm{n}=13,14\end{array}$ & $\begin{array}{c}\text { Erect } \\
\text { herb or under shrub }\end{array}$ & $\begin{array}{l}\text { R.P.R.C., BBSR. } \\
\text { LKA } 7650\end{array}$ \\
\hline $\begin{array}{l}\text { Chamaecrista absus (Linn.) Irwin \& Barneby } \\
\text { \{Senna absus (Linn.) Roxb. }\end{array}$ & $2 \mathrm{n}=26,28,56$ & Erect, viscid-hairy herb & $\begin{array}{l}\text { R.P.R.C., BBSR. } \\
\text { LKA } 7652\end{array}$ \\
\hline $\begin{array}{l}\text { Senna alexandrina Gars. ex Miller } \\
\text { (Cassia angustifolia Vahl) }\end{array}$ & $2 n=26$ & Herbs or shrubs & Keonjhar, Orissa. \\
\hline $\begin{array}{l}\text { Senna siamea (Lam.) Irwin \& Barneby } \\
\text { (Cassia siamea Lam.) }\end{array}$ & $2 \mathrm{n}=28$ & Moderate-sized tree & $\begin{array}{l}\text { R.P.R.C., BBSR. } \\
\text { LKA } 7625\end{array}$ \\
\hline Cassia fistula Linn. & $2 \mathrm{n}=28$ & Small or medium-sized tree & $\begin{array}{l}\text { R.P.R.C., BBSR. } \\
\text { LKA } 7644\end{array}$ \\
\hline $\begin{array}{l}\text { Cassia javanica Linn. var. javanica } \\
\text { (Cassia nodosa Buch-Ham. Ex Roxb.) }\end{array}$ & $2 \mathrm{n}=28$ & Deciduous trees & $\begin{array}{l}\text { R.P.R.C., BBSR. } \\
\text { LKA } 7630\end{array}$ \\
\hline $\begin{array}{l}\text { Senna pallida (Vahl) Irwin \& Barneby } \\
\text { (Cassia biflora Linn.) }\end{array}$ & $2 \mathrm{n}=28$ & Shrubs & $\begin{array}{l}\text { R.P.R.C., BBSR. } \\
\text { LKA } 7631\end{array}$ \\
\hline $\begin{array}{l}\text { Chamaecrista mimosoides (Linn.) Greene } \\
\text { (Cassia mimosoides Linn.) }\end{array}$ & $2 n=16,32$ & $\begin{array}{l}\text { Prostrate or decumbent } \\
\text { herbs or under shrub }\end{array}$ & $\begin{array}{l}\text { R.P.R.C., BBSR. } \\
\text { LKA } 7626\end{array}$ \\
\hline $\begin{array}{l}\text { Senna sulfurea (DC. ex Collad.) Irwin \& Barneby } \\
\text { (Cassia glauca Lam. Senna glauca Roxb) }\end{array}$ & $2 \mathrm{n}=28,56$ & Shrub or small tree & $\begin{array}{l}\text { OUAT Campus, } \\
\text { BBSR. LKA } 7648\end{array}$ \\
\hline Cassia grandis Linn. & $2 n=28$ & Trees & $\begin{array}{l}\text { R.P.R.C., BBSR. } \\
\text { LKA } 7642\end{array}$ \\
\hline Cassia javanica Linn.var. indochinensis Gagne & $2 \mathrm{n}=28, \mathrm{n}=12,14$ & Trees & Governer’s House, BBSR. LKA 7633 \\
\hline $\begin{array}{l}\text { Senna alata (Linn.) Roxb. } \\
\text { (Cassia alata Linn.) }\end{array}$ & $2 \mathrm{n}=12,24, \mathrm{n}=12,14$ & Shrubs or small trees & $\begin{array}{l}\text { Dhauli, BBSR. } \\
\text { LKA-7632 }\end{array}$ \\
\hline $\begin{array}{l}\text { Senna spectabilis (DC.) Irwin \& Barneby } \\
\text { (Cassia spectabilis DC.) }\end{array}$ & $2 \mathrm{n}=28$ & Evergreen trees & $\begin{array}{l}\text { I.G. Park, BBSR. } \\
\text { LKA } 7649\end{array}$ \\
\hline $\begin{array}{l}\text { Senna auriculata (Linn.) Roxb. } \\
\text { (Cassia aruiculaia Linn.) }\end{array}$ & $\begin{array}{l}2 \mathrm{n}=14,16,28 \\
\quad \mathrm{n}=14\end{array}$ & Large shrub & $\begin{array}{l}\text { Uppal, Hyderabad } \\
\text { A.P. LKA } 7641\end{array}$ \\
\hline Cassia roxburghii DC. & $2 \mathrm{n}=24,28$ & Small tree & Rajmahal Square, BBSR. LKA 7651 \\
\hline $\begin{array}{l}\text { Chamaecrista pumila (Lam.) Singh } \\
\text { (Cassia pumila Lam.) }\end{array}$ & $2 \mathrm{n}=28$ & Diffuse or prostrate herb & $\begin{array}{l}\text { R.P.R.C., BBSR. } \\
\text { LKA } 7647\end{array}$ \\
\hline $\begin{array}{l}\text { Senna septemtrionalis (Viv.) Irwin \& Barneby } \\
\text { (Cassia laevigata Willd.) }\end{array}$ & $2 n=26,28$ & Shrubs & $\begin{array}{l}\text { Dhauli, BBSR. } \\
\text { LKA } 7627\end{array}$ \\
\hline
\end{tabular}

calculate the RAPD primer index (RPI). RPI is the sum of the PIC of all the markers amplified by the same primer. Principal coordinate analysis (PCA) was used to retrieve information on the clustering pattern of the analyzed populations. PCA was performed based on the RAPD, ISSR and AFLP data, for all the primers.

\section{Results}

\section{Random Amplified Polymorphic DNA}

All the 18 species produced distinct reproducible amplifications. The DNA profiles as observed in RAPD are represented in (Fig. 1). A total of 612 numbers of bands were amplified (summary in Tab.2). All the bands were found to be polymorphic. Maximum and minimum amplification was observed in the case of the species Chamaecrista absus L. (139) and Cassia spectabilis L. (57) respectively. The highest numbers of bands were amplified with primer OPA02 and OPAO3 (36 each) and lowest numbers of amplification were observed with the primers OPC02 and OPN11 (17 loci each). Among the polymorphic bands 124 were exclusive bands, specific for a single species. Highest number of exclusive bands were observed for the primer OP N10 (10) while in the case of OP D02 and OP D20 only two bands were found to be exclusive. In Chamaecrista 

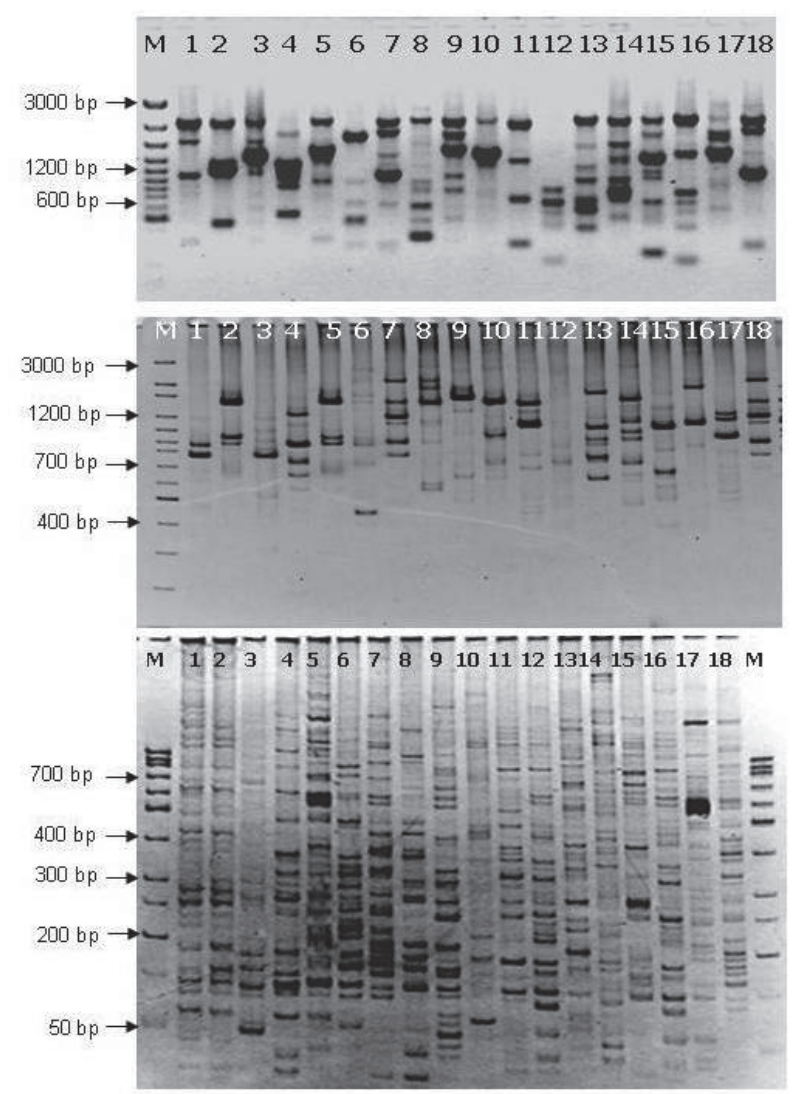

Figure 1. Banding pattern in different species of Cassiinae as seen in (from top to bottom) RAPD, ISSR and AFLP techniques

there were highest unique bands (20), only two bands were found to be unique in the case of Ch. pumila as well as for C. grandis. The dendrogram constructed using SHAN clustering shows three major groups among the 18 studied taxa (figure not shown).

\section{Inter Simple Sequence Analysis}

Six ISSR primers resulted in the amplification of 115 fragments. The ISSR banding pattern in Cassiinae is represented in Fig. 1. The primer (CAA) 5 and (GACA) 4 produced maximum number of bands (21), while with the primer(GA)9T only 14 loci could be amplified. Of these, only 8 were found to be unique bands. The bands were amplified in the range of 200-3000 base pairs. All the loci amplified with the ISSR primers were polymorphic and prominent. Maximum number of unique bands were observed with primer T (GA)9 (4), while there was no unique band with the use of primer (AGG)6, (GTG)5 and (CAA)5. Among these ISSR primers, maximum resolving power was obtained for (AGG)6 (12) and the minimum Rp was for (CAA) (5.78). Maximum primer index was calculated for (GACA) 4 and minimum for (CAA)5. Highest numbers of 36 bands were resolved for the species $C$. javanica and the least number of amplicons were amplified for the species $C h$. mimosoides. Details of ISSR banding pattern and bands amplified in different species with different primers have been represented in Tab. 3 .

\section{AFLP Analysis}

Six AFLP primer combinations were used for the present work. This primer combination had amplified 622 loci among which five loci were found to be monomorphic in nature and the rest were polymorhic. Banding pattern in AFLP for 18 species of Cassiinae is shown in Fig. 1. From the 594 polymorphic bands amplified, only 28 were found to be unique that to in a single species. Maximum numbers of 139 bands were resolved for the primer combination EACA/MCAG and the minimum for EACCA/MCAT (62). The average numbers of bands amplified per primer combination was calculated to be as high as 103.6. The highest numbers of bands (65) were noted for C. javanica var. indochinensis for primer combination EACT/MCAG and the lowest for the primer combination EACC/MCTC (19) in the case of the species C. javanica. Bands resolved between 1500bp to $20 \mathrm{bp}$ were taken into consideration for the present investigation. Maximum numbers of 3 monomorphic bands were scored for the primer combination EACC/ MCAT, whereas no band was found to be common to all the species with the primer combinations EACC/MCTC, EACT/MCAG, EACA/MCAG and EAAG/MCAC. The resolving power was maximum for the primer combination EAAG/MCAG (78.889) and minimum for EACC/MCTC (42.778). However, the primer index was found to be highest for EACA/MCAG (46.944) and lowest for EACC/MCAT (22.895). The details of AFLP analysis are presented in Tab. 4.

\section{Similarity for RAPD, ISSR and AFLP}

Jaccard's similarity was calculated from the data generated from RAPD, ISSR and AFLP analysis. It was observed that C. grandis and C. javanica var. indochinensis were most closely related with Jaccard's similarity coefficient of 0.473 , whereas Ch. mimosoides and S. sulfurea were distantly placed with the lowest Jaccard's similarity coefficient of 0.064 . Among all the species, there was average similarity of 0.1834 . Jaccard's similarity among the taxa is represented in Tab. 5 .

\section{Tree generated from the combined markers}

On the basis of the data obtained from all the molecular marker systems, a dendrogram was constructed using UPGMA and SHAN clustering in NTSYS-pc 2.02e (Fig. 2). All the 18 taxa of Cassinae studied were separated into three different clusters each containing members of a particular genus. The species of Senna were further divided into two subclusters each containg 5 species. While the first subcluster contained S. tora, S. occidentalis, S. alexandrina, S. siamea and $S$. pallida, the second had S. sulfurea, S. alata, S. spectabilis, 
Table 2. Details of RAPD analysis in Cassiinae.

\begin{tabular}{|c|c|c|c|c|c|c|}
\hline Primer & Sequence of oligonucleotide & Approx. fragment size & $\begin{array}{l}\text { Total } \\
\text { bands }\end{array}$ & $\begin{array}{l}\text { Unique } \\
\text { bands }\end{array}$ & $\begin{array}{c}\text { Resolving } \\
\text { power }\end{array}$ & $\begin{array}{l}\text { RAPD primer } \\
\text { index }\end{array}$ \\
\hline OPA02 & 5'TGCCGAGCTG3' & $>3000 \mathrm{bp}-300 \mathrm{bp}$ & 36 & 8 & 10.667 & 8.642 \\
\hline OPAO3 & 5'AGTCAGCCAC3' & $>3000 \mathrm{bp}-230 \mathrm{bp}$ & 36 & 7 & 13.222 & 9.8704 \\
\hline OPA04 & 5’AATCGGGCTG3' & $>3000 \mathrm{bp}-350 \mathrm{bp}$ & 26 & 3 & 8.222 & 6.6543 \\
\hline OPA10 & 5'GTGATCGCAG3' & $>3000 \mathrm{bp}-300 \mathrm{bp}$ & 28 & 4 & 10 & 7.8025 \\
\hline OPA16 & 5'AGCCAGCGAA3' & $>3000 \mathrm{bp}-200 \mathrm{bp}$ & 24 & 4 & 8.556 & 6.6358 \\
\hline OPA18 & 5’AGGTGACCGT3' & $>3000 \mathrm{bp}-200 \mathrm{bp}$ & 19 & 4 & 7.333 & 5.5802 \\
\hline OPAF14 & 5'GGTGCGCACT3' & $>3000 \mathrm{bp}-200 \mathrm{bp}$ & 23 & 7 & 5.889 & 4.821 \\
\hline $\mathrm{OPC} 02$ & 5'GTGAGGCGTC3' & $>3000 \mathrm{bp}-300 \mathrm{bp}$ & 17 & 4 & 5.667 & 4.4012 \\
\hline OPC05 & 5'GATGACCGCC3' & $>3000 \mathrm{bp}-200 \mathrm{bp}$ & 23 & 5 & 6.878 & 6.6111 \\
\hline OPD02 & 5'GGACCCAACC 3 ' & $>3000 \mathrm{bp}-300 \mathrm{bp}$ & 25 & 2 & 9.778 & 7.1481 \\
\hline OPD03 & 5'GTCGCCGTCA3' & $>3000 \mathrm{bp}-350 \mathrm{bp}$ & 22 & 3 & 8.111 & 6.142 \\
\hline OPD07 & 5'TTGGCACGGG3' & $>3000 \mathrm{bp}-350 \mathrm{bp}$ & 19 & 4 & 6.111 & 4.7222 \\
\hline OPD08 & 5'GTGTGCCCCA3' & $3000 \mathrm{bp}-300 \mathrm{bp}$ & 24 & 4 & 8.222 & 6.3086 \\
\hline OPD18 & 5'GAGAGCCAAC3' & $>3000 \mathrm{bp}-200 \mathrm{bp}$ & 30 & 7 & 11.222 & 7.8457 \\
\hline OPD20 & 5’ACCCGGTCAC3' & 2000 bp-300bp & 19 & 2 & 8.111 & 5.4877 \\
\hline OPNO2 & 5'ACCAGGGGCA3' & 3000bp-200bp & 27 & 7 & 8.667 & 6.7654 \\
\hline OPN04 & 5'GACCGACCCA3' & $3000 b p-200 b p$ & 31 & 4 & 12.444 & 9.1235 \\
\hline OPN05 & 5'ACTGAACGCC3' & $>3000 \mathrm{bp}-250 \mathrm{bp}$ & 22 & 4 & 6.778 & 5.4753 \\
\hline OPN06 & 5'GAGACGCACA3' & $>3000 \mathrm{bp}-100 \mathrm{bp}$ & 28 & 10 & 8 & 6.321 \\
\hline OPN08 & 5’ACCTCAGCTC3' & $>3000 \mathrm{bp}-400 \mathrm{bp}$ & 20 & 9 & 5.778 & 3.8025 \\
\hline OPN10 & 5'ACAACTGGGG3' & 3000bp-200bp & 23 & 6 & 7.556 & 5.9259 \\
\hline OPN11 & 5'TCGCCGCAAA3' & $>3000 \mathrm{bp}-400 \mathrm{bp}$ & 17 & 3 & 6.333 & 4.7593 \\
\hline OPN12 & 5'CACAGACACC $3 '$ & $>3000 \mathrm{bp}-200 \mathrm{bp}$ & 20 & 5 & 6.444 & 4.5556 \\
\hline OPN16 & 5'AAGCGACCTG3' & $>3000 \mathrm{bp}-100 \mathrm{bp}$ & 31 & 4 & 9.556 & 7.6914 \\
\hline OPN18 & 5'GGTGAGGTCA3' & $>3000 \mathrm{bp}-400 \mathrm{bp}$ & 22 & 4 & 7.222 & 5.7716 \\
\hline
\end{tabular}

Table 3. Details of ISSR analysis in Cassinae.

\begin{tabular}{|c|c|c|c|c|c|c|}
\hline Primer & Sequence of oligonucleotide & $\begin{array}{l}\text { Approximate } \\
\text { fragment size }\end{array}$ & $\begin{array}{l}\text { Total } \\
\text { bands }\end{array}$ & $\begin{array}{l}\text { Unique } \\
\text { bands }\end{array}$ & $\begin{array}{c}\text { Resolving } \\
\text { power }\end{array}$ & $\begin{array}{l}\text { ISSR } \\
\text { primer } \\
\text { index }\end{array}$ \\
\hline (AGG)6 & 5'AGG AGG AGG AGG AGG AGG3' & 2700bp-300bp & 19 & 0 & 13.33 & 7.2098 \\
\hline (GA)9T & 5'GAG AGA GAG AGA GAG AGA T3' & 2500bp-300bp & 14 & 3 & 7.8888 & 5.6419 \\
\hline$(\mathrm{GACA}) 4$ & 5'GAC AGA CAG ACA GAC A3' & $>3000 \mathrm{bp}-400 \mathrm{bp}$ & 21 & 1 & 10.8889 & 8.1667 \\
\hline $\mathrm{T}(\mathrm{GA}) 9$ & 5’TGAG AGA GAG AGA GAG AGA3’' & 2300bp-400bp & 20 & 4 & 8.33333 & 6.006 \\
\hline$(\mathrm{GTG})_{5}$ & 5’GTG GTG GTG GTG GTG3' & $>3000 \mathrm{bp}-400 \mathrm{bp}$ & 20 & 0 & 12 & 7.272 \\
\hline$(\mathrm{CAA})_{5}$ & 5'CAA CAA CAA CAA CAA3' & $>3000 \mathrm{bp}-100 \mathrm{bp}$ & 21 & 0 & 5.78 & 4.969 \\
\hline Total & & & 115 & 8 & & \\
\hline
\end{tabular}


Table 4. Details of AFLP analysis in Cassiinae.

\begin{tabular}{llccccc}
\hline Primer & $\begin{array}{c}\text { Sequence of } \\
\text { Primer }\end{array}$ & $\begin{array}{c}\text { Total } \\
\text { bands }\end{array}$ & $\begin{array}{c}\text { Mnomorphic } \\
\text { bands }\end{array}$ & $\begin{array}{c}\text { Unique } \\
\text { bands }\end{array}$ & $\begin{array}{c}\text { Resolving } \\
\text { power }\end{array}$ & $\begin{array}{c}\text { AFLP } \\
\text { primer index }\end{array}$ \\
\hline 1 & EACC/MCTC & 104 & 0 & 12 & 42.778 & 31.3148 \\
2 & EACT/MCAG & 98 & 0 & 2 & 60.111 & 37.10494 \\
3 & EAAG/MCAG & 116 & 2 & 1 & 78.889 & 43.333 \\
4 & EACC/MCAT & 62 & 3 & 1 & 45.889 & 22.89506 \\
5 & EACA/MCAG & 139 & 0 & 10 & 71.222 & 46.9444 \\
6 & EAAG/MCAC & 103 & 0 & 2 & 63.111 & 39.28395 \\
\hline Total & & 622 & & 28 & & \\
\hline
\end{tabular}

S. auriculata and S. septemtrionalis and both the subclusters shared a common node at approximately $23 \%$ level of similarity. All the species of Chamaecrista had a similarity of nearly $35.5 \%$ among themselves and Cassia at $32 \%$ similarity level. The tree had a common node at $11 \%$ similarity level for the three different genera in the subtribe Cassiinae.

\section{Cophenetic correlation}

Cophenetic correlation was calculated for different phenograms generated from three different marker systems. It was found that the maximum cophenetic correlation existed between C. grandis and C. javanica var. indochinensis (0.473). The cophenetic correlation for different markers is represented in Tab. 6. The average cophenetic correlation between any two species was found to be 0.183392 .

\section{Bootstrap analysis}

Bootstrap analysis revealed that all the clusters were stable and had bootstrap value of approximately 100. It indicates that the clades containing Cassia javanica and $C$. fistula among the members of Cassia, Chamaecrista pumila and Ch. mimosoides in Chamaecrista and Senna tora and S. occidentalis in Senna were closely linked with bootstrap value of 100 or nearly 100 . The bootstrap values among different clusters and subclusters were presented in the bootstrap tree. (Fig. 2).

\section{Principal coordinate analysis}

In the PRINCORD analysis, all the species were separated in three different plains each containing the representatives of a particular genus. All the species of Chamaecrista were grouped together at a corner in the PCA figure while all the members of Cassia were grouped in the opposite corner in the figure. However, the elements of Senna were found in the middle of the diagram maintaining equal distance from Cassia and Chamaechrista groups. The PCA diagram is represented in Fig. 3.

\section{Discussion}

The genomic relations among different taxa of Cassiineae were studied on the basis of RAPD, ISSR and AFLP fingerprinting. The relationship obtained among the different taxa of Cassinnae using RAPD was in agreement with the conventional taxonomic classification of the subtribe. The trifurcation of Cassiinae into three distinct genera as suggested by Irwin and Barneby (1981) proved to be justified. Whitty et al. (1994) worked on Cassiinae and justified the grouping of Cassia, Senna and Chamaecrista. We observed similar type of result. However, the intrageneric relationship among species of Senna does not follow the sequence that Irwin and Barneby (1981) worked out. The three species represented here of sect. Peiranisia namely, S. pallida, S. auriculata and S. spectabilis formed a cluster. Similarly, S. tora, S. occidentalis, S. septemtrionalis and S. siamea all belonging to sect. Chamaefistula, came together in a distinct clade. Non-inclusion of S. alexandrina in the above cluster could not be reasoned out. Of the three elements of the genus Chamaecristra, the lone species of sect. Grimaldia i.e. Ch. absus got separated from the other two, which belong to sect. Chamaecrista. The infra-generic arrangement of species in Chamaecrista was in agreement with Irwin and Barneby (1981). The deviations with regard to intrageneric relationships may be due to selection of a small number of species from such a large taxon for the present investigation and amplification a small portion of the entire genome. Souza \& Benko-Iseppon (2004) found significant differences in chromosome size, morphology and condensing behavior among members of the controversial tribe Cassieae (Cassia, Chamaecrista and Senna), revealing the tribe to be a heterogeneous group from the karyological point of view.

In contrast, the species relationship in the genus Cassia as observed from RAPD tree was confusing. The distant placement of C. javanica and C. roxburghii, both belonging to the series Obolospermae (Irwin \& Barneby 1981) and even separation of two varieties of $C$. javanica could not be suitably explained. Inclusion of more species and resorting 


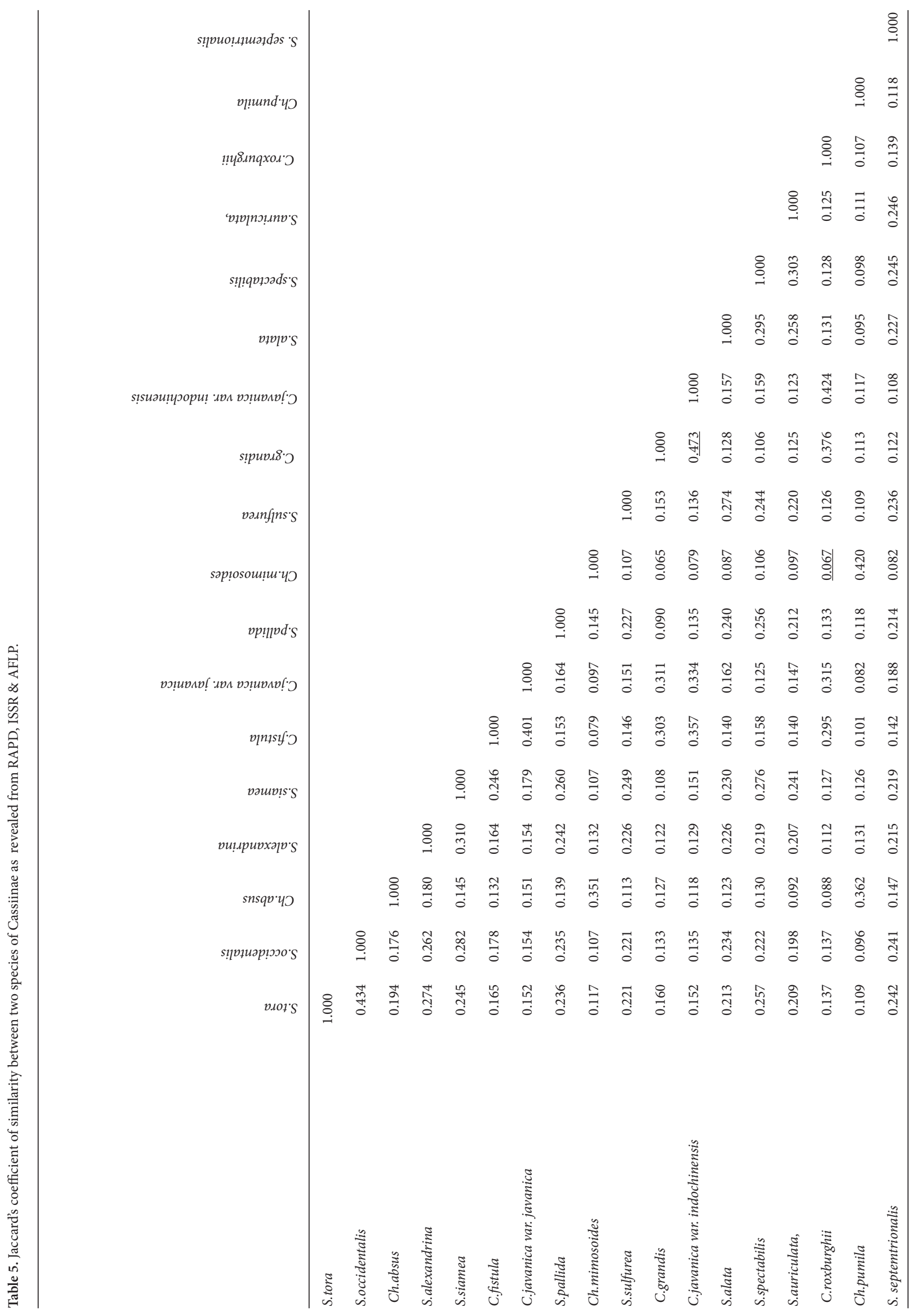




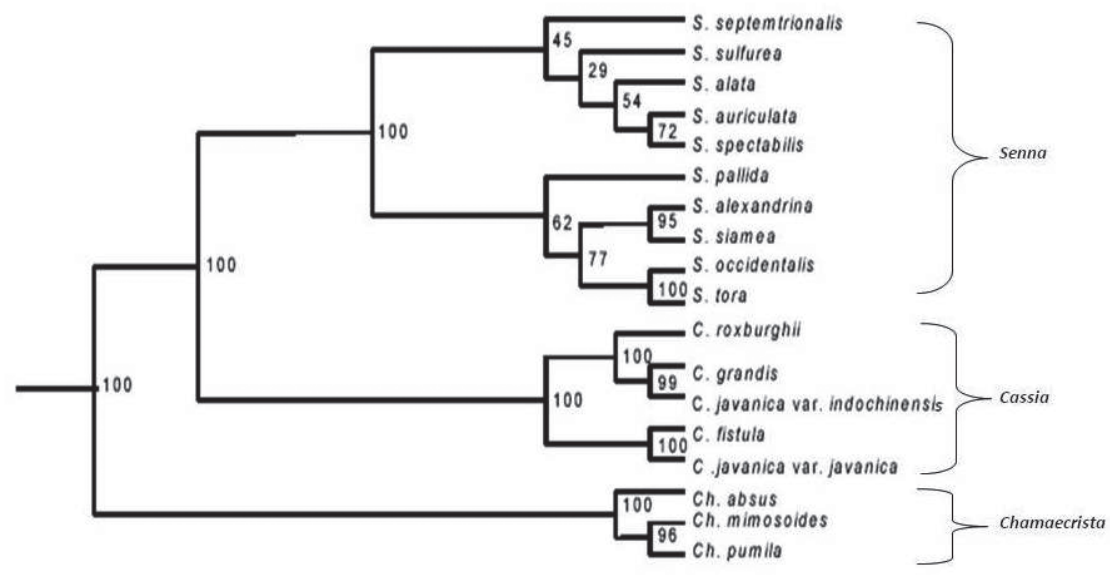

Figure 2. Dendrogram showing genomic relationship and bootstrap value among and within different clusters in Cassiinae as revealed from RAPD, ISSR and AFLP data.

to other molecular techniques in conjunction with RAPD are likely to alter the arrangement of taxa under the genus and bring about the expected order.

The dendrogram obtained from the ISSR data segregated the subtribe into two clusters; the first with the three species of Chamaecrista and the second having all the species of Cassia and Senna. The second clade was further bifurcated to two subclusters; one with all 10 species of Senna and the second subcluster had five species belonging to the genus Cassia. Thus, broadly there was a segregation of the subtribe Cassiinae into three genera. This was in conformity with the classification proposed by Irwin \& Barneby (1981). Though the division of the subtribe on the basis of ISSR data appears justified, the clustering and arrangement of species under Senna and Cassia were not at par with the traditional grouping made earlier. As in the case of RAPD, in the genus Chamaecrista, Ch. absus that comes under sect. Grimaldia got separated from the remaining two and Ch. mimosoides and Ch. pumila formed a subcluster justifying their inclusion under sect. Chamaecrista.

In the Cassia clade, C. javanica var. indochinensis and $C$. roxburghii, which are closely related came in a single cluster with distantly related C. grandis. But the other variety $C$. javanica var. javanica remained isolated and formed a clade with C. fistula. The placement of the four species of Cassia under the three series Cassia, Grandes and Obolospermae was not possible. Similarly, from the dendrogram generated from ISSR data, segregation of species of Senna into traditionally recognized sections like Psilorhegma, Peiranisia, Chamaefistula and Senna also could not be done. Though only six ISSR primers were used for the present investigation, the result was comparable with the RAPD.

As both RAPD and ISSR were dominant markers and arbitrarily amplified the loci the need for application of better marker system was felt and AFLP was used. Six
AFLP primer combinations were used for deciphering the genetic relationship among the 18 species of Cassiinae and a total of 622 bands were obtained, most of which were polymorphic in nature. A high degree of genetic diversity among the species of Cassiinae was noted. The dendrogram constructed on the basis of the data obtained from the AFLP analysis segregated the subtribe into three distinct groups. As observed in RAPD and ISSR analysis, all members of Senna, Cassia and Chamaecrista formed distinct clusters. The arrangement of species under the genera Chamaecrista and Cassia was exactly similar as determined from RAPD and ISSR analysis and described earlier. However, the species of Senna were clustered in two groups; the first cluster containing S. tora, $S$. occidentalis, S. alexandrina, S. siamea and S. pallida and the second cluster with the remaining five species. All the five species of the first subcluster shared a common node at $34 \%$ similarity level; S. tora and S. occidentalis were the closest. The second subcluster consisted of S. sulfurea, $S$. alata, S. spectabilis, S. auriculata and S. septemtrionalis and shared a node with the first subcluster at about $27 \%$ level of similarity. The species arrangement did not follow any logical pattern and the data obtained was not discernible.

Marazzi et al. (2006) studied phylogenetic relationships within Senna based on parsimony analyses of three chloroplast regions ( $r p S 16, r p L 16$, and $m a t K$ ) and provided new insights on the evolution of floral symmetry and extrafloral nectaries. Their results supported the monophyly of only one sect. Psilorhegma of the six currently recognized sections, while Chamaefistula, Peiranisia, and Senna were paraphyletic and monotypic Astroites and Paradictyon were nested within two of the seven major clades identified by molecular phylogeny. Their investigation further suggested that flowers in Senna were ancestrally monosymmetric with seven fertile stamens and three adaxial staminodes, switched to asymmetry later, and reverted to monosymmetry in most 


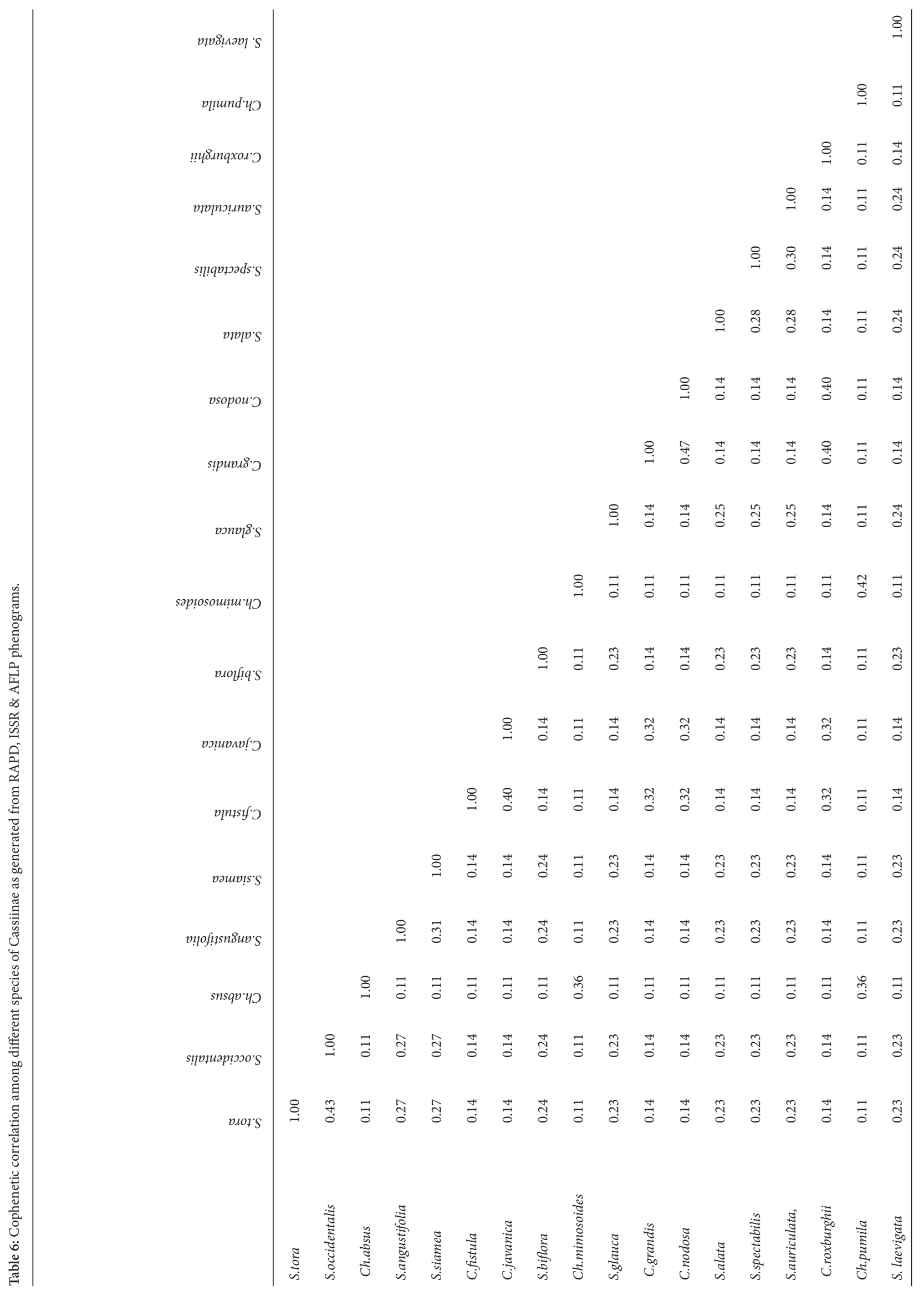




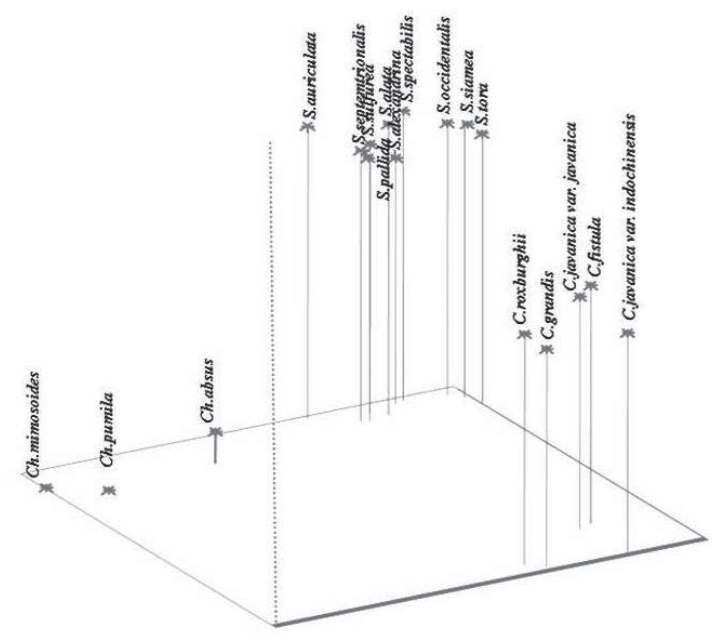

Figure 3. Principal co-ordinate analysis showing cluster arrangement in Cassiinae.

advanced clade. Fertility of all 10 stamens was considered to be a derived state, characterizing the Psilorhegma subclade.

The phenogram constructed using combined data from RAPD, ISSR and AFLP analyses exhibited similar relationships among the genera and species. The bootstrap value obtained for different groups was fairly good which indicated that the branching in the tree was stable. When the correlation among all the markers was calculated it was highly encouraging and all markers showed high degree of correlation with each other and with the combined data.

Data obtained from analysis through molecular markers revealed high degree of genetic diversity among the different taxa of Cassiinae. Similar observations were made by other authors who worked on the subtribe taking different morphological markers (Bhattacharya \& Maheshwari, 1971; Lasseigne 1979); Malik \& Krishna 1978; Shyam et al. 1983; Mathur 1985; Shyam \& Vartak, 1985; Bhattacharya \& Saha, 1992; Sahai et al. 1997). In the present study taking the molecular markers into account the trifurcation of the subtribe Cassiinae could be re-established but the intrageneric classification and phylogeny in different genera of the subtribe needs to be worked out in detail taking large number of species and using sophisticated molecular marker systems such as SSR and sequence-based markers like cp-DNA, nr DNA and ITS regions.

\section{References}

Ali, S.I. \& Quraishi, S. 1967. A taxonomic study of the genus Cassia L. from West Pakistani Sindh University Research Journal (Sciences series) 3: 1-13.

Bhattacharya, A. \& Saha. P.K. 1992. SEM studies on the morphological diversities in the seeds of Cassia tara L. Seed Science and Technology 20: 85-91.

Bhattacharya, B. \& Maheshwari J.K. (1971) Studies on extrafloral nectalies of the leguminales. Proceedings of the Indian Natural Science Academy 37: 11-30.
De Wit, H.C.D. 1955. A revision of the genus Cassia (Caesal.) as occurring in Malaysia. Webbia 11: 197-292.

Gherardi, M.; Mangin, B.; Goffinet, B.; Bonnet, D. \& Huguet T. 1998. A method to measure genetic distance between allogamous populations of alfalfa (Medicago sativa) using RAPD molecular markers. Theoretical and Applied Genetics 96: 406-412.

Ghislain, M.; Zhang D.; Fazardo D.; Huamann, Z. \& Hismans, R.H. 1999. Marker-assisted sampling of the cultivated Andean Potato Solanum fureja collection using RAPD markers. Genetic Resources and Crop Evolution 46: 547-555.

Irwin, H.S. \& Barneby, R.C. 1981. Tribe Cassieae Bronn. Pp. 97-106. In Polhill, R.M. \& Raven, P.H. (Eds.) Recent Advances in Legume Systematics, pt 1. Kew, Royal Botanic Garden.

Irwin, H.S. \& Barneby R.C. 1982. The American Cassiinae-a synoptical Revision of Leguminosae tribe Cassiae subtribe Cassiinae in the New World. Memoirs of the New York Botanical Garden 35: 1-918.

Jaccard, P 1908. Nouvelles recherches sur la distribution florale. Bulletin de la Société Vaudoise des Sciences Naturelles 44: 223-270.

Larsen, K. \& Hou, D. 1996. Caesalpiniaceae. Pp. 556-570, 673-691. In Hou, D.; Larsen, K. \& Larsen, S.S. (Eds.) Flora Malesiana, v. 12, n. 2. Amsterdam, Foundation of Flora Malesiana.

Lasseigne, A. 1979. Studies in Cassia (Legume-Caesal.): External seed morphology. Iselya 1: 63-80.

Lock, J.M. 1988. Cassia senso lat. (Leguminosae-Caesalpinioideae) in Africa. Kew Bulletin 43: 333-342.

Lock, J.M. 1989. Legumes of Africa: a check-list. Kew, Royal Botanic Gardens.

Malik, K.C. \& Krishna, B. 1978. Identification of seeds of Indian Senna of commerce. Bulletin of Botanical Survey of India 20: 113-116.

Marazzi, B.; Endress, P.K.; Queiroz, L.P. \& Conti, E. 2006. Phylogenetic relationships within Senna (Leguminosae, Cassiinae) based on three chloroplast DNA regions: patterns in the evolution of floral symmetry and extrafloral nectaries. American Journal of Botany 93: 288-303.

Mathur, M. 1985. Comparative structure of epidermal structure and seed analysis of two Cassia species. GeoBios new reports 4: 96-97.

Prevost, A. \& Wilkinson M.J. 1999. A new system of comparing PCR primers applied to ISSR fingerprinting of potato cultivars. Theoretical and Applied Genetics 98: 107-112.

Randel, B.R. 1988. Revision of the Cassiinae in Australia. 1. Senna Miller Sect. Chamaefistula (Colladon) Irwin \& Barneby. Journal of the Adelaide Botanic Garden 11: 19-49.

Randel, B.R. 1989. Revision of the Cassiinae in Australia. 2. Senna Miller Sect. Psilorhegma (J. Vogel) Irwin \& Barneby. Journal of the Adelaide Botanic Garden 12: 165-270.

Randel, B.R. 1990. Revision of the Cassiinae in Australia. 1. Senna Miller Sect. Chamaefistula. Journal of the Adelaide Botanic Garden 13: 1-16.

Rohlf, F.J. 1997. NTSYS-pc Numerical Taxonomy and Multivariate Analysis System. New York, USA, Exeter Software, Set-auket.

Saghai-Maroof, M.A.; Soliman, K.M.; Jorenson R.A. \& Allard R.W. 1984. Ribosomal DNA spacer length polymorphism in barley: Mendelian inheritance, chromosomal location and population dynamics. Proceedings of the Natural Academy of Science (USA) 81: 80148018 .

Sahai, K.; Kaur, H. \& Pal, A. 1997. Macro and micro morphological seed characteristics of some Cassia species and their taxonomic significance. Phytomorphology 47: 273-279

Shyam, A.K.; Vartak V.S. \& Kumbhojkar, M.S. 1983. Observations on the seed morphology of Cassia L. Biooigyanum 9: 39-46.

Shyam, A.K. \& Vartak V.D. 1985. Seed morphology of Indian Caesalpinaceae; Cassia. Seed Science Technology 13: 699-712.

Singh, V. 2001. Monograph of Indian subtribe Cassiinae (Caesalpinaceae). Journal of Economic and Taxonomic Botany, Additional series 18 . Jodhpur India, Scientific Publisher.

Smith, J.S.C.; Chin, E.C.L.; Shu, H.; Smith, O.S.; Wall, S.J.; Senior, M.L.; Mitchell, S.E.; Kresovich, S. \& Ziegle, J. 1997. An evaluation of the utility of SSR loci as molecular markers in maizes (Zea mays L.): Comparison of data from RFLPs and pedigree. Theoretical and Applied Genetics 95:163-173. 
Sneath, P.H.A. \& Sokal, R.R. 1973. Numerical Taxonomy. San Francisco, California, W.H. Freeman and Company.

Souza, M.G.C. \& Benko-Iseppon A.M., 2004. Cytogenetics and chromosome banding patterns in Caesalpinioideae and Papilionoideae species of Pará, Amazonas, Brazil. Botanical Journal of the Linnean Society 144: 181-191.

Vos, P.; Hogers, R.; Bleeker, M.; Reijans, M.; van de Lee, T.; Hornes, M.; Fritjers, A., Pot J.; Peleman, J.; Kuiper, M. \& Zabeau, M. 1995. AFLP: a new technique for DNA fingerprinting. Nucleic Acids Research 23: 4407-4414.

Whitty, P.W.; Powell \& Sprent, J.L. 1994. Molecular separation of genera in Cassiinae(Leguminosae) and analysis of variation in the nodulating species of Chamaecrista. Molecular Biology 3: 507-515.

Williams, J.G.K.; Kubelik, A.R.; Livak, K.J.; Rafalski, J.A. \& Tingey, S.V. 1990. DNA polymorphisms amplified by arbitrary primers are useful as genetic markers. Nucleic Acids Research 18: 6531-6535. 